\title{
Globalization of Communicable Animal Diseases - - A Crisis of Veterinary Medicine
}

\section{KOUBA}

Former Chief, Animal Health Service, Food and Agriculture Organization of the United Nations

Received May 5, 2003

Accepted September 22, 2003

\begin{abstract}
Kouba V. : Globalization of Communicable Animal Diseases - A Crisis of Veterinary Medicine. Acta Vet. Brno 2003, 72: 453-460

The analysis of globalization of animal diseases is based on official reports on communicable disease introductions through international trade. Number of available reports on these cases during 1980-2000 reached 607: 117 OIE List A disease cases (including 33 of foot-and-mouth disease), 365 OIE List B disease cases (74 of multiple animal species diseases, 142 of cattle diseases, 42 of sheep and goat diseases, 29 of horse diseases, 12 of pig diseases, 49 of avian diseases, etc.), 108 OIE List $C$ disease cases and 17 cases of other diseases. The import of diseases transmissible to man was reported 212 times (34.93\%). Cases of disease reappearance, i.e. newly imported or reemerged after 3 and more years, were reported 329 times. Number of reports on animal disease "recognized in country for the first time" reached 420 cases. All reported data represent only "the tip of the iceberg". Disease import is usually followed by spreading that is extremely difficult to control, often not manageable and with catastrophic consequences. Very limited number of successful communicable disease control and eradication programmes together with all recoveries of individual diseased animals cannot compensate for at all rapidly increasing animal population morbidity in the world. No one animal disease has been globally eradicated as yet. Disease import devaluates the results of control and eradication programmes. Diseases are spreading as never in the past when the trade used to be of much minor size and intensity at much shorter distances to much lesser number of destination places. The situation is getting worse every day towards a man-made global ecological irreparable disaster. Continuing worldwide mass spreading of communicable diseases, not being blocked by effective measures, represents serious global crisis of veterinary medicine the historical mission of which is to promote, protect and recover animal health.
\end{abstract}

Animal population morbidity, infectious disease, disease export, disease import, disease reappearance, disease spreading, disease first discovery, international trade, post-import spread

Key criterion of veterinary medicine historical mission is its practical impact on global animal population health. The usefulness of this scientific branch depends on how far it is able to protect healthy animals, to recover health of diseased animals and to reduce, eliminate and eradicate diseases. Unfortunately, available facts document serious discrepancy between rapidly increasing amount of scientific knowledge and rapidly worsening of animal health global situation. Among main causes belongs the propagation of infectious and parasitic diseases through international trade in animals and their products. Increasing public health, economic, ecological, social and animal welfare negative impacts of diseases spreading are enormous. The purpose of this paper is to analyze globally communicable diseases spreading through international trade from 1980 when regular reporting on animal disease import was started. Analysis of previous periods was published by Blancou and Meslin (1995) using unofficial literature sources only. Import of animals and animal products represents a risk not only of disease introduction but also of post-import spreading with multiplying negative, often long-term or permanent, catastrophic consequences. Unfortunately, due to immense diversity of individual diseases under

Address for correspondence:

Prof. MVDr. Václav Kouba, DrSc.

P.B. 516

17000 Praha 7

Phone: +420233381088 http://www.vfu.cz/acta-vet/actavet.htm 
different conditions it was not possible to elaborate any international standards for objective measuring of epizootiological risks (OIE 1993). The majority of imported diseases cannot be blocked within short quarantine if any. Discovery in time, successful control and eradication of introduced and spread diseases are usually extremely difficult and very often practically impossible.

The analysis is based on country official data as reported by the governments to international organizations. Data on international trade are from FAO Trade Yearbook (FAO 1966-2002). Data on diseases introduction through trade are from two international yearbooks - OIE World Animal Health (OIE 1991-2002) and FAO-WHO-OIE Animal Health Yearbook (FAO 1980-1996) (international collection of data on "disease import" was introduced by the author when he was its Editor-in-Chief). The analysis is supported by the examples from FAO and OIE documents as well as from literature sources. International information system is based only on etiological agent species structure regardless of enormous number of their different strains, serotypes, etc. which can often represent exotic danger for the importing country. This information system covers only about $1 / 10$ of known species of transmissible diseases, including 1/5 of known zoonoses. The system does not include conditionally pathogenic agents, strains resistant to treatment means, etc.

Many countries did not send the regular annual reports or only incomplete ones and therefore their data were not available for the inclusion in this analysis. The number of reporting countries varied from 110 (1983) to 169 (1991); in average about 75\% countries only. There are a lot of cases of animal disease import, some are discovered and reported to international organizations, many are discovered and not reported (e.g., most diseases are not obligatory notifiable and not controlled), many more cases are discovered too late for reporting them as imported, and even many more cases are not discovered at all (e.g., subclinical carriers). Therefore, the analysis could not be complete, i.e. it covered only a small part of the reality which is much worse than officially reported.

Important factor was the degree of detectability (sensibility) of available diagnostic methods and the grade of reporting on disease import cases. Some cases were reported with delay due to late discovery of imported diseases which creates difficulties in controlling them. The delay was usually related to long incubation periods which can be up to several months (e.g. paratuberculosis) or several years (e.g. BSE) as well as to the ability of veterinary service to detect imported disease in time.

The analysis of reports on animal disease introductions through international trade was subdivided according to international classification of communicable diseases: OIE Lists A, $\mathrm{B}$ and $\mathrm{C}$. In case of reporting the import of the same disease in following year or repeatedly during the same year, only one report was included in this quantitative analysis. The available reports were related mainly to disease import through trade in live animals. Microscopic pathogens import through animal products (such as Salmonella spp. in fresh meat) was very difficult to identify due to their rapid distribution, processing and consumption and quite insufficient etiological investigations.

Additionally, there were analyzed the numbers of reports on specific disease "recognition in country for the first time". Many of them were imported from abroad. Analysis of reports on specific disease reappearance (reimported or reemerged) includes only cases which reappeared after 3 and more years. The reason is that the reappearance after less than 3 years could be in some cases the result of the pathogens survival in animal-carriers or in the environment.

In 1996 FAO-WHO-OIE Animal Health Yearbook disappeared and regular reporting on diseases import cases, on diseases recognition for the first time and on diseases reappearance was abolished by the International Office of Epizootics (OIE). Therefore, later these data found in the OIE World Animal Health yearbooks were only ad hoc ones. The analysis based 
on official numeric facts was complemented (when specific data for global quantification were not available) by selected examples from the literature to document certain aspects of international disease spreading. Particular attention was given to the ratio primary/secondary outbreaks expressing the grade of disease post-import spreading.

Spread of diseases spread through international trade is directly correlated with increasing import of animals and animal products. According to FAO Trade Yearbooks international legal import of these commodities increased during 1961-2000 in monetary values 17 times (from 4653 to 80358 million US\$). The import of meat and meat products, sharing the major proportion (56\%) of animal trade, increased 20 times (from 2202 to 44764 million US\$). It can be estimated that national trade in these commodities increased analogically. It is obvious that the risk of disease spreading increased simultaneously. In 2000 the international trade reached $22920710 \mathrm{MT}$ of meat and meat products (daily average $62796 \mathrm{MT}$ ), 19697079 MT of dairy and eggs (daily average 53965 MT), 8159000 heads of cattle (daily average 22353), 15254937 sheep (daily average 41794), 16644537 pigs (daily average 45601) and 755006000 chickens (daily average 2068510). This amount of traded commodities facilitated a huge daily stream of pathogens passing through not always effective anti-epizootic "filters" in exporting and then in importing countries.

International trade in animals and animal products during 1980-2000 caused spread of many animal diseases. Number of cases officially reported to international organizations on diseases import reached 607 (Table 1).

Table 1

Number of country reports on the introduction of communicable diseases through animal import, world, 1980-2000

\begin{tabular}{|llcc|}
\hline OIE Code & Animal Species & Number of reports & \% \\
\hline List A diseases & multiple & 117 & 19.28 \\
\hline List B diseases & multiple & 74 & 12.19 \\
& cattle & 142 & 23.39 \\
& sheep and goats & 42 & 6.92 \\
& horses & 29 & 4.78 \\
& pigs & 12 & 1.98 \\
& poultry & 49 & 8.07 \\
& others & 17 & 2.80 \\
& Subtotal & 365 & 17.79 \\
\hline List C diseases & & 108 & 2.80 \\
\hline Others diseases & & 17 & $\mathbf{1 0 0 . 0 0}$ \\
\hline Total & & $\mathbf{6 0 7}$ & \\
\hline
\end{tabular}

Sources: FAO/WHO/OIE Animal Health Yearbook (1980-1996) and OIE World Animal Health yearbook (1991-2002) Note: In 1996 special regular reporting on disease "import" was abolished, i.e. later reports were only ad hoc.

From 117 OIE List A disease cases the major shares had foot-and-mouth disease - FMD $(28.23 \%)$, rinderpest $(17.09 \%)$, Newcastle disease $(14.53 \%)$, contagious bovine pleuropneumonia (7.69\%), classical swine fever $(5.98 \%)$ and bluetongue $(5.13 \%)$.

The structure of 365 OIE List B disease cases was as follows: From 74 multiple species disease cases the major shares had paratuberculosis, echinococcosis, screwworm (Cochliomyia hominivorax), rabies, anthrax and heartwater. From 142 cattle disease cases the major shares had bovine leucosis, tuberculosis, brucellosis, IBR-IPV, babesiosis, anaplasmosis, theileriosis, BSE and cysticercosis. From 42 sheep and goat disease cases the major shares had caprine arthritis/encephalitis, maedi-visna, ovine epididymitis, brucellosis 
(B. melitensis), ovine pulmonary adematosis and scrapie. From 29 equine disease cases the major shares had equine piroplasmosis, equine viral arteritis, equine infectious anaemia and contagious equine metritis. From 12 swine disease cases the major shares had atrophic rhinitis and porcine cysticercosis. From 49 avian disease cases the major shares had Marek's disease, avian chlamydiosis, infectious bursal disease, mycoplasmosis and infectious laryngotracheitis. From 17 other disease cases the major shares had leishmaniosis, rabbit haemorrhagic septicaemia and bee acariosis.

From 108 OIE C disease cases the major shares had distomatosis, warble infestation, avian leucosis, caseous lymphangitis, mucosal disease, contagious pustular dermatitis and filariosis. From 17 other disease (outside of the OIE information system) cases the major share had Ebola-Marburg virus infection, influenza-parainfluenza and sheep babesiosis.

Number of reports on animal diseases ,recognized in country for the first time“, i.e. imported or discovered with delay, reached 420. Disease reappearance, i.e. reintroduced or reemerged, was reported 329 times. The analysis includes only reports of the reappearance when the interval between last previous and new cases was 3 and more years. (Table 2). The longest periods were reported on FMD reappearance in Japan after 92 years, in Taiwan after 67 years and in Korean Republic after 66 years.

Table 2

Country reports on reappearance of animal communicable diseases, world, 1980-2000

\begin{tabular}{|ccc|}
\hline Intervals in years & Number of reports & \% \\
\hline $3-10$ & 240 & 72.97 \\
$11-20$ & 49 & 14.89 \\
$21-30$ & 18 & 5.47 \\
$31-40$ & 13 & 3.95 \\
$41-50$ & 1 & 0.30 \\
$51-60$ & 0 & 0.00 \\
$61-70$ & 5 & 1.55 \\
$>70$ & 2 & 0.61 \\
$?$ & 1 & 0.30 \\
\hline Total & $\mathbf{3 2 9}$ & $\mathbf{1 0 0 . 0 0}$ \\
\hline
\end{tabular}

Sources: FAO/WHO/OIE Animal Health Yearbook (1980-1996) and OIE World Animal Health yearbook (1991-2002)

Within the total of reported cases following proportions were represented by diseases transmissible to man (zoonoses): $34.93 \%$ of reports on disease import, $15 \%$ of reports on specific disease discovery for the first time and $30.51 \%$ of reports on disease reappearance (Kouba 2001) (Table 3). The majority of known zoonoses is not included into OIE disease lists (e.g. plague, Ebola-Marburg virosis, Salmonella typhimurium in mammals, trichophytosis, etc..).

Table 3

Number of country reports on cases of the import of animal communicable diseases, their first discovery and reappearance (total and zoonoses), world, 1980-2000

\begin{tabular}{|lcrc|}
\hline Report Type & Number of cases & Zoonoses & \% \\
\hline Imported & 607 & 212 & 39.93 \\
Discovered for the first time in history (incl. imported cases) & 420 & 63 & 15.00 \\
Reappeared after 3 and more years (incl. imported cases) & 329 & 130 & 30.51 \\
\hline
\end{tabular}

Source: FAO/WHO/OIE Animal Health Yearbook (1980-1996) and OIE World Animal Health yearbook (1991-2002) Note: In 1996 special regular reporting on these cases was abolished, i.e. later data were only ad hoc. 
The majority of communicable disease import cases (about 70\%) was reported from developing world with about $25 \%$ of global animal import where the impacts are very serious due to weak veterinary services and lack of means to control imported diseases (Kouba 2000).

To document the difficulty to discover particular diseases and to report true disease situation following example is used: "It is assumed, that for every case of salmonellosis recorded in humans in the United States at least nine are not reported" (Toma et al. 1999, p. 147). It is obvious that the reporting on animal diseases reality is similar or worse. Following example of the late discovery of imported diseases is used: "In 2000 varroosis was identified in New Zealand for the first time. The results of investigations suggested that the parasite had been introduced three or four years before" (OIE 2000, p. 235).

All transmissible diseases spread at different speed and extent, mostly unnoticed due to subclinical forms. Almost free spreading is characteristic for diseases outside of veterinary control, i.e. for the majority of diseases. Many communicable diseases are able to penetrate the barriers even of the best isolated and controlled laboratories. Example: "In 1978, the Plum Island Animal Disease Research Center, identified foot-and-mouth disease (type O) in cattle in a holding area on the Island near the Laboratory." (FAO 1979). It is logical that under field conditions the spreading of diseases is much easier.

The ratio primary/secondary outbreaks, expressing the grade of disease post-import spreading, is documented by following examples: "In Taiwan FMD occurred in 1997 and stormed the whole island that led to tremendous economic impact. During four months a total of 6,147 farms was infected !" (OIE 1997, p. 317-318); the ratio = 1 : 6147. In the European Union during 1977-1987 the average ratio primary/secondary outbreaks of FMD was 1:54 (Davies 1993). In UK in 2001 this ratio reached 1:2030 (Sterneberg and Choraine 2002).

Other important criterion is represented by territorial spread of imported diseases. Example: "In 1988 was discovered for the first time in the Eastern Hemisphere the horrible myiasis Cochliomyia homivorax, affecting all mammal species including man, imported by sheep from American continent; during several months it invaded $25000 \mathrm{~km}^{2}$ in the North Africa with more than 2.7 million domestic animals" (FAO 1992).

\section{Discussion}

There were many cases when, in spite of favourable risk assessment, risk reducing measures and international standard veterinary certification, specific diseases spread through import into countries free of these diseases or contributed to worsening of existing situation. Examples see in Table 4 (these data, as not reported to OIE or FAO as imported cases, were not included in the global analysis numbers mentioned above).

In the majority of communicable diseases clinical investigation alone is not able to discover the true situation which is therefore unknown and these diseases can freely spread unnoticed. Emerging diseases, new more virulent and resistant strains represent an insidious threat even for human health and life.

Many introduced diseases cannot be blocked in the quarantine to avoid secondary outbreaks. Late discovery gives the chance for territorial spreading making impossible the application of effective eradication measures in time. The recovery, i.e. eradication, is feasible only in very limited number of diseases due to lack of necessary methods and inputs. Even the countries considered as the best prepared had difficulty to block and eradicate imported diseases. Example: Eradication of FMD introduced in United Kingdom in 2001 cost the life of 3964000 animals (Sterneberg and Choraine 2002). (FMD is clinically easier to detect than the majority of communicable diseases). This case demonstrated the enormous complexity, diversity and dynamics of the diseases as biological phenomena and the difficulties to control imported diseases. 
Disease first introduction into countries previously specifically free is particularly lamentable. Dramatic consequences had the import of cattle subclinically affected by BSE conducing to significant reduction of production and consumption of beef in many countries. Other example: paratuberculosis of cattle imported to this disease-free Czech Republic (Pavlík et al. 2001) is now widely spread and there is no real chance to eradicate it.

Disease reintroduction represented serious impact due to devaluation of successful eradication which was usually very demanding, expensive and requiring a long period. In one moment the result of many years of intensive work was converted into zero. In the Czech Republic, Chroust et al. (1997) wrote about reintroductions of different cattle parasites which had already been eradicated such as hypodermosis, dictyocaulosis and paramphistomosis. Other examples see in Table 4.

Table 4

Number of animal disease introductions through legal import (with official certificates) to the Czech Republic, 1990-1996

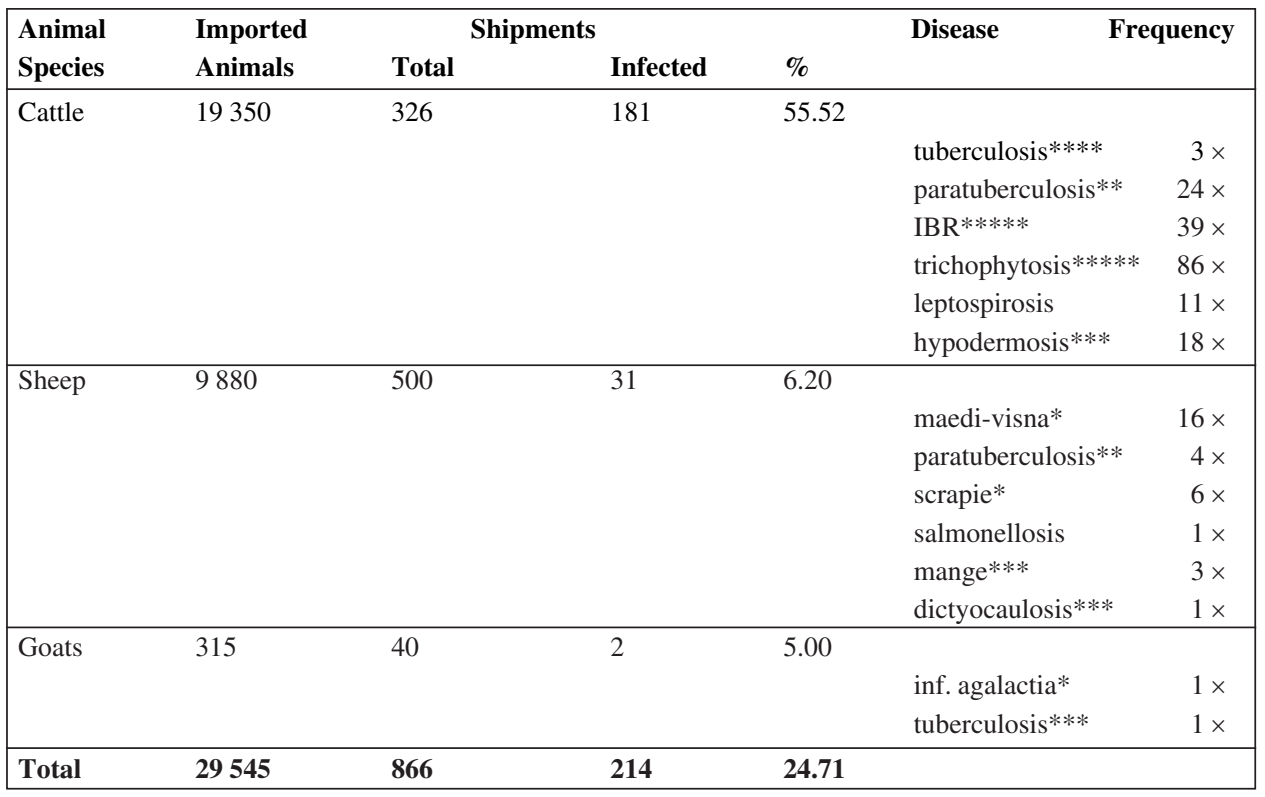

Situation before 1990: * never recorded; ** never recorded in indigenous animals (exceptional occurrence only in some imported animals); $* * *$ eradicated; $* * * *$ eliminated (free status according to OIE Code); ***** very advanced eradication programme.

Note: Animals were imported mostly from West European countries.

Source: State Veterinary Administration, Prague, Czech Republic

Eradication of imported diseases, mainly so called exotic ones, is extremely difficult and costly. Example: Eradication of Cochliomyia hominivorax, introduced through trade into North Africa from South America, cost circa 80 million US\$ (losses not included) (FAO 1992); as usually profiting exporters contributed nothing.

There were also cases of conscious spreading of infected, or suspect to be infected, commodities into many countries. Example: "A large rendering company in UK continued and expanded its export of meat and bone meal, which may have been contaminated with BSE, for 8 years after EU ban in 1988, to 70 countries in the Middle and Far East" (Hodge s 2001). 
Serious problem is represented by different regional strains unknown in other regions and considered there as exotic. Their introduction complicates the diagnosis and anti-epizootic measures. Example: "Globalization also means global scope for diseases that were previously limited to specific regions. The rapid spread of the FMD Pan-Asian strain is witness to this. As UK outbreak has spread to France and the Netherlands, it appears that FMD is a global threat and that the only real solution is to tackle the problem at its source" (FAO 2001).

\section{Conclusion}

The analysis proved an alarming worsening of animal health in the world during the recent period. Available data used for this analysis represent only a small "tip of the iceberg", i.e. the true situation is by far worse than reported. The spreading of diseases through international trade is directly correlated with disease occurrence, degree of true situation ignorance and degree of disease control deficiency in exporting countries, trade size and frequency as well as with the numbers and distances between origin and destination places. (Analyses identifying factors facilitating diseases spreading through international trade and identification of correcting measures require separate papers.)

Weakened (somewhere ad absurdum) public veterinary services are very often not able to assure disease-free or pathogen-free animal export and to manage disease import cases. Veterinary services are able to recover health and save life of many diseased animals, solving mostly local problems. However, simultaneously larger numbers of animals become infected, invaded and clinically sick due to diseases spreading mainly through trade. The analysis documents clearly that the globalization of communicable diseases of animals started. There is a real risk that next generations will blame us for leaving them the animal health global situation much worse than it was before. The lesson for the future was published by Kouba (2002) recommending the steps for avoiding further deterioration of global epizootiological situation.

Increasing intensity of international trade in animals and animal products caused increasing spread of diseases among countries and continents. The situation has been getting worse than ever, in spite of having much better scientific knowledge as in previous periods. Very few successfully finished national eradication programmes are unable to compensate for rapidly spreading of animal diseases in the whole world. Too many results of disease control and eradication achieved by previous generations of veterinarians were gradually devaluated through disease import which demotivates the efforts to start new programmes or continue the existing ones.

The situation is approaching every day towards man-made irreparable global ecological disaster. Continuing worldwide mass spreading of communicable diseases, not being blocked by effective measures, represents serious global crisis of veterinary medicine the historical mission of which is to promote, protect and recover animal health in the whole world.

\section{Globalizace přenosných nemocí zvířat - krize veterinární mediciny}

Analýza globalizace nemocí zviŕat se opírá o oficiální zprávy o zavlečení přenosných nemocí mezinárodního obchodem se zviřaty a jejich produkty. Počet těchto zpráv, které byly k dispozici za období let 1980-2000 činil 607:117 případů velmi nebezpečných nemocí ze seznamu A Mezinárodního úřadu pro nákazy (OIE) včetně 33 případů importu slintavky, 365 př́padů nemocí ze seznamu $\mathrm{B}$ (74 případů nemocí postihujících více než jeden druh zvířat, 142 případů dalších nemocí skotu, 42 případů nemocí ovcí a koz, 29 případů nemocí koní, 12 prŕípadů nemocí prasat, 49 případů nemocí drůbeže, atd.), 108 případů nemocí ze 
seznamu C a 17 př́ípadů jiných nemocí. Import nemocí přenosných na člověka byl hlášen ve 212 případech $(34.93 \%)$. Případy znovuobjevení přenosných nemocí, tj. nově importované anebo opět zjištěné po 3 a více letech, byly hlášeny 329 krát. Počty hlášených případů, kdy daná přenosná nemoc se zjistila po prvé v zemi, dosáhly 420 . V̌šchny tyto údaje představují pouze ,„̌pičku ledovce“. Import přenosných nemocí je zpravidla následován jejich šířením, velmi obtižně kontrolovatelným, často nezvládnutelným s katastrofickými následky. Velmi omezený počet úspěšných ozdravovacích a eradikačních programů proti přenosným nemocem zviřrat spolu s vyléčenými nemocnými jednotlivými zviřaty nemohou vůbec kompenzovat rychle se zvyšující celkovou nemocnost zviŕă ve světě. Ani jedna nemoc zvíră ještě nebyla globálně eradikována. Import nemocí znehodnocuje dosažené výsledky ozdravovacích a eradikačních programů. Nemoce zvířat se šírí jako nikdy v historii, kdy mezinárodní obchod býval podstatně menšího rozsahu, na mnohem kratší vzdálenosti a mezi značně menším počtem míst. Situace se zhoršuje každým dnem směrem $\mathrm{k}$ nenapravitelné člověkem způsobené globální ekologické katastrofě. Pokračující masové šîrení přenosných nemocí ve světě, nezadržované účinnými opatřeními, představuje i vážnou globální krizi veterinární mediciny, jejímž hlavním historickým posláním je vytvářet, chránit a obnovovat zdraví animálních populací.

\section{References}

BLANCOU, J, MESLIN, FX 1995: International trade and human or animal diseases: a historical review. Proceedings of the World Veterinary Congress, Yokohama: p. 4.

CHROUST, K, BÍLY, V, PAVEL, V 1997: Podkožní střečkovitost (hypodermóza) skotu a její tlumení. Veterinářství, 47: 514-515 (in Czech)

DAVIES, G 1993: Risk assessment in practice: a foot and mouth disease control strategy for the European Community. Rev Sci Tech Off Int Epiz 12: 1109-1120

FAO 1966-2002: FAO Trade Yearbook. Rome

FAO 1979: FAO-OIE-WHO Animal Health Yearbook, Rome, p. 53

FAO 1980-1996: FAO-OIE-WHO Animal Health Yearbook. Rome

FAO 1992: The New World screwworm eradication programme. Rome, $191 \mathrm{pp}$.

FAO 2001: Empres. Rome, 16: 10

HODGES, J. 2001: Editorial. Livestock Production Science 69, p. 59

KOUBA, V 2000: Analysis of diseases spreading through international trade in animals in developing countries. Agricultura Tropica et Subtropica, Prague Agriculture University 33: 70-74

KOUBA, V 2001: Globalizace animálních infekcí a mezinárodní obchod. Zprávy Centra epidemiologie a mikrobiologie, Státní zdravotní ústav, Praha 10: 483-485 (in Czech)

KOUBA, V 2002: History of diseases spreading through international trade - lesson for the future. World Veterinary Association Bulletin 19 18-21

OIE. 1993: Risk analysis, animal health and trade. Rev Sci Tech Off Int Epiz 12: 1005-1362 OIE: 1991-2002: World Animal Health (Yearbook). Paris

PAVLÍK, I, BAŽANT, J, VITÁSEK, J 2001: Paratuberkulóza skotu dovezeného do České Republiky. Veterinářství 51: 159-163 (in Czech)

STERNEBERG, T, CHORAINE, P 2002: Foot and Mouth Disease. World Veterinary Association Bulletin 19

TOMA, B, VAILLANCOURT, J-P, DUFOUR, B, ELOIT, M, MOUTOU, F, MARSH, W, BÉNET, J, SANAA, M, MICHEL P 1999: Dictionary of Veterinary Epidemiology, Iowa State University Press, Ames, 147 p. 